\title{
Neglected rare human parasitic infections: Part IV: Hirudiniasis
}

Review

Article

\author{
Wael M Lotfy
}

Department of Community Health Nursing, Faculty of Nursing, Matrouh University, Egypt

\begin{abstract}
Among all species of leeches, only true leeches especially jawed leeches are known to attack humans. These species are either freshwater or land dwellers. Freshwater leeches of medical importance may be divided into two groups: leeches which attack the mucous membranes (endoparasites), and those that attack the skin (ectoparasites). Some species of the former group have been incriminated in causing halazoun, while many species of the latter group were used in bloodletting. Leeches may be potential transmitters of human pathogens. The land leeches are much less fearsome than the aquatic leeches. However, the harm which land leeches cause to man and his domestic animals may be such that some infested foci become almost uninhabitable. This review summarizes current knowledge on the public health significance of true leeches as human parasites and their medical uses, and the recommended methods of prevention and control.
\end{abstract}

Keywords: Annelida, leech, man, public health, segmented worms.

Received: 17 January, 2021, Accepted: 22 February, 2021.

Corresponding Author: Wael M Lotfy, Tel.: +20 1008154959, E-mail: waelotfy@mau.edu.eg

Print ISSN: 1687-7942, Online ISSN: 2090-2646, Vol. 14, No. 1, April, 2021.

True leeches (Hirudinea: Euhirudinea) are segmented worms belonging to the phylum Annelida. Some species are marine, others are terrestrial, and the majority are freshwater dwellers ${ }^{[1]}$. They are dorsoventrally compressed; the dorsal side is convex, and the ventral side flattened or concave. True leeches are characterized by a very elastic body capable of contraction and extension. Each individual leech has two suckers for attachment: a small anterior one that surrounds the oral opening, and a larger posterior one. True leeches are hermaphrodites, but cross fertilization between two individuals usually occurs to produce eggs that are deposited in groups, often in a capsule called cocoon ${ }^{[2]}$.

There are several difficulties associated with the systematics and taxonomy of euhirudins, thus it is in need of reviewing ${ }^{[3-5]}$. Euhirudins are generally classified into two groups: Rhynchobdellida (proboscis leeches) and Arhynchobdellida (proboscisless leeches). Noteworthy, all rhynchobdellids are jawless, and many arhynchobdellids have jaws. Arhynchobdellids may be either predaceous carnivores or hematophagous and are divided into two orders Pharyngobdellae (worm-leeches) and Gnathobdellae (jawed leeches). Members of the Pharyngobdellae do not have the ability to penetrate a host's tissue and suck blood. They are carnivorous and equipped with a relatively large, toothless, mouth to ingest the prey. Members of the Gnathobdellae have a jaw filled with hundreds of tiny sharp teeth. They are to a considerable degree sanguivorous adapted for the engorgement with relatively large amounts of blood ${ }^{[6]}$. Almost all species of medically important leeches are found in the Gnathobdellae.
They colonise freshwater (Hirudidae or Hirudinidae) and terrestrial (Haemadipsidae and Xerobdellidae) environments ${ }^{[1,3,5,7]}$. The hematophagous leeches are usually not particular about their victims. Animals are the primary hosts of such leeches and man is only accidently affected. Bites of jawed leeches are painless and result in a tri-radiate lesion which remains open for a long period and heals slowly due to the hirudin anticoagulant peptide secreted by the salivary gland of the leech. Leeches are temporary parasites because they attack victims only for feeding and drop off when they are engorged. They withdraw for prolonged periods to sheltered places and slowly digest the accumulated food ${ }^{[8,9]}$.

Rare reports documenting accidental human infections with true leeches are available in the literature, but only fragmentary information is available. A literature search was carried out using Google Scholar. Textbooks were also searched online using Google Books.

\section{Fresh water leeches}

Aquatic leeches that threaten humans are divided into endoparastites attacking the mucous membranes and ectoparasites attacking the skin. Members of the former group have weak jaws adapted for feeding on soft tissues such as the mucosa of the upper aerodigestive tracts. Members of the latter group have relatively powerful jaws that can penetrate the skin and attach anywhere on the external surface of the body ${ }^{[10]}$.

Leeches which attack mucous membranes: The jawed leeches that are adapted to cutting human (or 
animal) thin mucous membranes instinctively locate and reach these membranes. These leeches have been described in many sites as the oesophagus, conjunctiva, mouth, pharynx, larynx, nose, trachea/bronchi, vagina, bladder, and rectum. Human infections occur by acquiring the leech through drinking or bathing in infested water ${ }^{[11-15]}$.

The best-known species of this group is the Nile leech, Limnatis nilotica, found in the Middle East, North Africa, and southern Europe. It extends as a far as Iran, Tajikistan in the east and Azores in the west ${ }^{16,17]}$. It is the most common species of leech in Egypt and Lebanon ${ }^{[16]}$. Limnatis nilotica inhabits lakes and streams, and rarely marshes. They usually crawl on the bottom or attach themselves to stones or plants. They swiftly swim in a snake-like fashion towards the prospective animal or human victim. This species rarely bites the skin; it usually reaches the mouth or nostrils of the victim while drinking, then attaches itself to the mucosa. It normally attacks mammals and may attack the skin of frogs. However, it would eventually be swallowed and digested by frogs. On attachment, L. nilotica adheres its anterior sucker to the soft parts of the mouth or to the bucco-pharyngeal cavities, leaving its body flopping freely ${ }^{[18,19]}$. In heavy infections, especially in animal hosts, leeches attach themselves to the gums, under the tongue or the upper parts of the respiratory tracts as well[ ${ }^{[20-27]}$. In the human body, usually, a single leech settles in the pharynx or in the upper part of the respiratory tract. The leech remains in the host for periods varying from several days to several weeks ${ }^{[28]}$, causing mechanical injury and anaemia ${ }^{[25-27]}$. The mechanical injury may result in swelling of the invaded organs, interfering with swallowing or breathing ${ }^{[29]}$. Leeches can ingest an amount of blood equivalent to $890 \%$ of their body weight $^{[25]}$.

In some instances, a leech may remain in the throat for days without provoking any symptoms. If swallowed to the stomach, the leech immediately dies. The clinical presentations are laryngopharyngitis and a crawling sensation in the throat called halazoun or marrara $^{[30,31]}$. The word halazoun in Arabic means snail, but here it means that the causative organism has a coiled appearance. Limnatis nilotica is one of the reported parasitic causes of halazoun in the Middle East ${ }^{[27,30,32]}$. The leech can enter very narrow ducts, such as the human and animal urethra or cattle teat canals ${ }^{[10,16,33]}$. Reports on cases of leech attachment to the eye are available in the literature ${ }^{[12]}$.

Species of L. imnatis can always attack victims during its life. It does not fill its digestive tract in one feed, as does Hirudo medicinalis, but does this at intervals while attached. When fully engorged, the leeches detach themselves as the animal starts drinking again and thus escape to the outer water source, where they hide in crevices or under stones to digest the accumulated blood meal. The digestive organs of L. nilotica are empty three to four weeks after the meal. However, the leech may survive long periods of starvation ${ }^{[10,18,19]}$.

Human hirudiniasis due to L. nilotica was described by Savigny, who accompanied Napoleon's Army to Egypt. In 1799 when the army marched from Egypt to Syria across the Sinai, the soldiers drank water from leech-infested ponds. The leeches attached themselves to the mucous membranes of their oral cavity and throats. The soldiers suffered great torment by these leeches which in some cases caused death from either suffocation or bleeding. A similar condition was experienced by British soldiers in the Sinai in World War I, and by American troops in Vietnam ${ }^{[34]}$. Infection is not common in humans, and sporadic reports are available in the literature especially from the Middle East and adjoining countries ${ }^{[21]}$. Due to the popularization of tap-water usage in endemic countries, cases of this kind of leech infection have rarely been reported in recent years ${ }^{[35]}$.

In addition to $L$. nilotica, several other species were reported to attack humans. Limnatis paluda was identified in Central Asia and in some Middle Eastern countries where it sometimes coexists with $L$. nilotica ${ }^{[36-38]}$. In addition, Dinobdella ferox was reported in Southeast Asia ${ }^{[39-41]}$, and Myxobdella africana in subSaharan Africa ${ }^{[22,43]}$. In the USA, Macrobdella decora ${ }^{[44]}$, M. sestertii ${ }^{[45]}$, and $M$. diplotertia ${ }^{[46]}$ may attack humans. Tyrannobdella rex attacks humans in Peru ${ }^{[47]}$.

Different approaches were applied for the safe removal of this group of leeches from an infected host. These attempts vary from using forceps for immediate extraction to the use of various tranquilizing agents for the leech and to relieve pain as the parasite is being removed ${ }^{[48,49]}$. Leech extraction from the larynx may be performed by direct laryngoscopy, with the patient under general or topical/local anesthesia. A leech attached to the nostrils or the upper pharynx, is detached by application of 1:10,000 adrenalin, $30 \%$ cocaine, or dimethyl phthalate. An alternative technique is by irrigation with strong alcohol, saline, turpentine, or vinegar to disconnect the leech. It is advisable not to grasp a leech with forceps because it has a soft slippery skin that may rupture easily ${ }^{[50]}$. It is important to avoid firm traction while pulling off the leech so as not to leave parts of its mouth behind, leading to continuation of bleeding and secondary infection $^{[51]}$.

Leeches that attack the skin: The ectoparasitic hematophagous leeches prefer to live in still or slowly flowing freshwaters, although specimens have been collected from fast flowing streams. They are activated by sudden swirling of water, when people and animals entering the water presumably attract leeches by the impact produced. Then, the leeches attach themselves 
to the human or animal skin with whom they come in contact and actively suck blood ${ }^{[8,9]}$.

This group of leeches was used for medical purposes for centuries. Although its origin remains obscure, the first recorded use of leeches for local depletion of blood dates far back to ancient Egypt (1567-1308 BC). During the Medieval period, the use of leeches in getting rid of bad blood became popular with European and Arabian physicians. Medicinal leeches were sold to physicians and patients by apothecaries ${ }^{[52-54]}$. During this period, leech bloodletting was preferred to the painful mechanical methods. The medical use of leeches reached its peak in the first half of $19^{\text {th }}$ century ${ }^{[53]}$. During the latter half of the same century, the medicinal use of leeches did not conform with modern medicine concepts and it was almost completely neglected ${ }^{[54]}$. However, there remained some justification for the use of the leech in certain cases of thrombosis or phlebitis, and possibly in selected types of hypertension without anaemia ${ }^{[55]}$. In 1960, the first treatment of venous congested flaps using leeches was conducted to avoid thrombosis ${ }^{[56]}$.

During the last few decades, medicinal leech therapy became more acceptable in the field of plastic and reconstructive surgery ${ }^{[54,57-62]}$. This came with the identification of a variety of useful bioactive peptides and proteins in leech saliva: anti-thrombin (hirudin, bufrudin), anti-platelet (calin, saratin), factor Xa inhibitors (lefaxin), anti-bacterial (theromacin, theromyzin) and others ${ }^{[63,64]}$. In July 2004 , the use of leeches as a medical aid gained approval by the FDA ${ }^{[65]}$. Although the medicinal leech is known as a long-time vector of all types of blood transmitted pathogens, apparently it does not directly transmit pathogens via the injection of contaminated saliva ${ }^{[66-69]}$. Thus, it is advisable to discard a leech after it has been used for a therapeutic purpose ${ }^{[69]}$. Probably bacterial infection is the most common complication associated with medicinal leeching and occurs in $2-36 \%$ of the patients. Several bacterial strains have been encountered in these infestations involving Aeromonas spp., Pseudomonas spp. and Vibrio spp. ${ }^{[60,64]}$.

The most common leeches used medically are those of the genus Hirudo ${ }^{[70-73]}$. Among them, $H$. medicinalis (syn. H. officinalis Savigny, 1822) was reported in Britain and in southern Norway to the southern Urals, probably as far as the Altai Mountains. Hirudo nipponia was used medically in East Asia, including Far East district in Russian, Japan, Korea, China, Mongolia, Ryukyu Islands and Taiwan. Besides, Hirudo. orientalis (Transcaucasian countries, Iran, and Central Asia), H. troctina (North-Western Africa and Spain), $H$. uinquestriata (Australia), and $H$. verbana (Switzerland and Italy to Turkey and Uzbekistan) were recorded ${ }^{[70-73]}$. Hirudo medicinalis was once common all over Europe. Leech collection, for about two centuries, resulted in its disappearance from many localities $^{[74,75]}$. Nowadays, this species is protected by international conventions and regulations ${ }^{[76]}$. The genus Poecilohdella (syn. Hirudinaria) includes $\sim$ nine species that may be indicated for bleeding of patients. They can pierce the thickest skin and viciously attack animals and man under natural conditions. Rice field workers in endemic foci suffer much from these species. Probably the most important species are $P$. granulosa in the upper plains of India, P. manilensis in the lowlands of the whole tropical South-West of Asia, while $P$. javanica is found in the Sunda Islands and Burma ${ }^{[77]}$. The medicinal leech $H$. medicinalis is found in its natural habitats in Egypt, where all records of this species from the Nile River refer to it as L. nilotica and therefore can be misidentified. It is noteworthy that L. nilotica which naturally attacks mucous membranes has been used for bloodletting in Egypt since ancient times ${ }^{[78]}$. Another leech that naturally attacks mucous membranes is the North American medical leech Macrobdella decora. It is considered less efficient than $H$. medicinalis. In addition to jawed leeches, some proboscis leeches (rhynchobdellids) of the genus Haementeria have been used for medical purposes. These species are Haementeria officinalis in Central America, and both Haementeria depressa and Haementeria ghilianii in South America ${ }^{[1,70]}$.

An easy method for removal of skin leeches is by the fingernail or another suitable object to detach the oral sucker at the anterior end of the leech, then the posterior sucker. As the fingernail is pushed along the victim's skin against the leech, the suction of the sucker's seal is broken, and the jaws are disconnected ${ }^{[79]}$. Although medically inadvisable, common methods to remove attached leeches are to apply a flame, a lit cigarette, salt, soap, or a chemical such as alcohol, lemon juice, vinegar, insect repellent, heat rub, or some carbonated drinks. By these applications the leech quickly detaches, regurgitating its stomach contents into the wound. The leech vomit may carry some pathogens, and thus increase the risk of infection ${ }^{[79]}$. Hydroxycitronellal which has a sweet floral aroma is an effective repellent against both aquatic and land leeches ${ }^{[80]}$.

\section{Land leeches}

They are a group of hematophagous terrestrial species belonging to different genera that are adapted to life in damp forests with high humidity. Most species are found in tropical and subtropical areas of the IndoPacific Asia. There are 10 unusual and lesser-studied land species found in isolated foci in subtropical or temperate regions of Central and South America, and Europe ${ }^{[9]}$. Global warming may be blamed for the gradual extinction of European land leeches ${ }^{[81]}$. Up to now, the taxonomy of land leeches is not fully understood, especially at the species level ${ }^{[4,5,82,83]}$. Land leeches are placed in the two families; Haemadipsidae and Xerobdellidae. There are some 60 species of blood-feeding land leeches, $\sim 50$ belong to the family 
Haemadipsidae, and the rest are placed in the family Xerobdellidae $^{[1]}$. Many genera of land leeches in the family Haemadipsidae are found in tropical regions surrounding the Indian and Pacific Oceans (especially Madagascar, Sri Lanka, Malaysia, and Japan). Although haemadipsids exhibit high biodiversity, they are characterised by peculiar anatomical structures which make them distinct from related families ${ }^{[84-87]}$. Members of this family feed on blood, except for a few species of the genus Idiobdella that are adapted to eating small snails ${ }^{[87]}$. Most of the known haemadipsids represent the genus Haemadipsa. The best studied species are representatives of the genera Haemadipsa and Philaemon. The genus Haemadipsa prevails in Asia and Indonesia, while the genus Philaemon prevails in Australia and South America ${ }^{[86-89]}$. Surprisingly, little is known about their biology, probably because biologists believe that they do not transmit human pathogens ${ }^{[90]}$.

In their natural habitats, land leeches are usually found wandering along grasses or standing erect on their posterior sucker and waving their bodies. Land leeches are exceptionally efficient in attacking a passing man (or animal). They climb on to the lower branches of trees or shrubs to a height of about four feet and wait for the victim on the edges of the leaves. To their surprise, people strolling in enzootic foci discover the leeches hanging on to their skin mostly on the legs or might feel trickling of blood after the leeches have fallen off. Land leeches can crawl on to their host even while moving. They rapidly creep between the tight clothes and even through the holes of the shoe laces aiming to reach the skin which they pierce painlessly ${ }^{[91,92]}$. The genus Haemadipsa was recorded to ingest $\sim 1,000 \mathrm{mg}$ of blood in 10 minutes ${ }^{[93]}$. The land leech sucks blood for 40-120 minutes and then drops off. Hundreds of leeches can attack a man within a short time. Blood continues to stream from the wound for $\sim 30$ minutes washing away the hirudin allowing the closure of the wound by a clot. Usually, the wound heals by itself, but, sometimes, if the affected place is not thoroughly cleaned, secondary infection may complicate the condition. In cases of massive infestation, the loss of blood may be considerable, and it may even cause death, especially in animals. Land leeches may attach themselves to the eye causing blindness. Areas dominated by leeches causing harm to man and his domestic animals become almost uninhabitable. During the World War II, the land leeches posed a problem to soldiers fighting in the forests of Myanmar (formerly Burma) and Malaysia. In enzootic foci, land leeches disappear during the dry season, burrowing into the soil or creeping under logs, to reappear when the damp conditions of the rainy season have returned. The land leeches are much less fearsome than the aquatic ones ${ }^{[8,9,91,92]}$.

Field control of land leeches with chemicals and insecticides was unsuccessful because of the vast forested areas involved, difficult terrain and harmful effects on the environment and non-target species ${ }^{[94]}$. Garments, however tight, do not offer sufficient protection in enzootic foci. Repellents are recommended to prevent leech bite, either in the form of an ointment applied on the exposed body parts or by impregnation of the clothes. Repellent-impregnated cloth sleeves for legs was reported to give protection up to 90 days. The use of essential oils and plant extracts provided promising results ${ }^{[95]}$. Repellents of plant origin are preferred over synthetic repellents as prolonged use of the latter could be harmful due to their toxicity and chemical nature ${ }^{[96]}$.

Conclusion: Several species of true leeches, either freshwater or land dwellers, can attack the human body. Additionally, they may be potential transmitters of human pathogens. Although medicinal leech therapy has been used for centuries, it has recently enjoyed a comeback in the field of plastic and reconstructive surgery. True leeches, especially land leeches, are among the most neglected human parasites. More studies are needed to be carried out in endemic foci to gain a better understanding regarding their biology and taxonomy.

Conflict of interest: There is no conflict of interest.

\section{REFERENCES}

1. Sket B, Trontelj P. Global diversity of leeches (Hirudinea) in freshwater. Hydrobiologia 2008; 595(1):129-137.

2. Buchsbaum R, Buchsbaum M, Pearse J, Pearse V. Animals without backbone. $3^{\text {rd }}$ ed. Chicago, IL: The University of Chicago Press; 1987.

3. Trontelj P, Sket B, Steinbruck G. Molecular phylogeny of leeches: congruence of nuclear and mitochondrial rDNA data sets and the origin of bloodsucking. J Zool Syst Evol Res 1999; 37:141-147.

4. Borda E, Siddall ME. Arhynchobdellida (Annelida: Oligochaeta: Hirudinida): phylogenetic relationships and evolution. Mol Phylogenet Evol 2004; 30(1):213225.

5. Borda E, Oceguera-Figueroa A, Siddall ME. On the classification, evolution and biogeography of terrestrial haemadipsoid leeches (Hirudinida: Arhynchobdellida: Hirudiniformes). Mol Phylogenet Evol 2008; 46(1):142-154.

6. Mann KH. Leeches (Hirudinea): Their structure, physiology, ecology and embryology. Oxford, UK: Pergamon Press; 1962.

7. Elliott JM, Kutschera U. Medicinal leeches: Historical use, ecology, genetics and conservation. Freshw Rev 2011; 4(1):21-41.

8. Keegan HL, Toshioka S, Suzuki H. Blood sucking Asian leeches of families Hirudinidae and Haemadipsidae: Biomedical Reports of the 406 Medical Laboratory No. 16. US Army Medical Commend, Japan; 1968. 
9. Sawyer RT. Leech biology and behaviour. Oxford, UK: Clarendon Press; 1986.

10. Witenberg G. Hirudiniases. In: van Hoeden J, editor. Zoonoses. New York, NY: Elsevier Publishing Company 1964; pp 710-719.

11. Lepage P, Serufilira A, Bossuyt M. Severe anaemia due to leech in the vagina. Ann Trop Paediatr 1981; 1:189190.

12. Alcelik T, Cekic O, Totan Y. Ocular leech infestation in a child. Am J Ophthalmol 1997; 124(1):110-112.

13. Kaygusuz I, Yalcin S, Keles E. Leeches in the larynx. Eur Arch Otorhinolaryngol 2001; 258(9):455-457.

14. Idris MA. Vaginal hirudiniasis from Dhaherah Province, Oman: With a note on internal hirudiniasis. Sultan Qaboos Univ Med J 2006; 6(2):83-86.

15. Sapmaz E, Toplu Y. Unusual cause of epistaxis; leech infestation in the nose. Interlink Continental J Med Med Sci 2014; 1(1):1-3.

16. Orevi M, Eldor A, Giguzin I, Rigbi M. Jaw anatomy of the blood-sucking leeches, Hirudinea Limnatis nilotica and Hirudo medicinalis, and its relationship to their feeding habits. J Zool 2000; 250(1):121-127.

17. Grosser C, Pesic V. On the diversity of Iranian leeches (Annelida: Hirudinea). Arch Biol Sci 2006;58(1):2124.

18. Shevkunova EA. Certain data on biology of feeding of Limnatis nilotica (Savigny, 1820). Med Parazitol (Mosk) 1955; 24(4):346-351.

19. Negm-Eldin MM, Abdraba MA, Benamer HE. First record, population ecology and biology of the leech Limnatis nilotica in the Green Mountain, Libya. Travaux de l'Institut Scientifique, Rabat (Série Zoologie) 2013; 49:37-42.

20. Seyfarth C. Tropische und subtropische Süsswasserblutegel als Parasiten im Menschen. Zbl Bakt Hyg 1 Abt Orig 1917; 79:89-96.

21. Marschak A. Parasitological aspects of ENT practice in Israel. Harefuah 1958; 54(2):47-48.

22. Almallah Z. Internal hirudiniasis in man with Limnatis nilotica, in Iraq. J Parasitol 1968; 54(3):637-638.

23. Al Safadi MM, El-Shimy NA. Freshwater leeches from Yemen. Hydrobiologia 1993; 263:185-190.

24. Nesemann H, Forster R. First record of Limnatis nilotica from Oman (Hirudinea: Hirudinidae). Miscnea Zool Hung 1997; 11:11-14.

25. 25.Al-Hadrani A, Debry C, Faucon F, Fingerhut A. Hoarseness due to leech ingestion. J Laryngol Otol $2000 ; 114: 145-146$.

26. Cheikh-Rouhou F, Besbes M, Makni F, Chaabouni M, Ayadi A. Limnatis nilotica causing severe anaemia in an infant. Med Trop (Mars) 2000; 60(1):100-101.

27. Agin H, Ayhan FY, Gulfidan G, Cevik D, Derebasi H. Severe anemia due to the pharyngeal leech Limnatis nilotica in a child. Türkiye Parazitoloji Dergisi 2008; 32:247-248.

28. Chen WC, Chien CY, Yang CH, Li JH, Hwang CF. Nasal leech infestation: Report of seven leeches and literature review. Eur Arch Otorhinolaryngol 2010; 267(8):1225-1229.
29. Solomon E. Leech: An unusual cause of (laryngotracheal) obstruction. Ethiop Med J 1991; 29(3):141142.

30. Witenberg G. What is the cause of the parasitic laryngo-pharyngitis in the Near East ("Halzoun")? Acta Med Orient 1944; 3:191-192.

31. Chung DI, Moon CH, Kong HH, Choi DW, Lim DK. The first human case of Clinostomum complanatum (Trematoda: Clinostomidae) infection in Korea. Korean J Parasitol 1995; 33(3):219-223.

32. Watson JM, Kerim RA. Observations on forms of parasitic pharyngitis known as halzoun in the Middle East. J Trop Med Hyg 1956; 59(7):147-154.

33. Swanson LE. Leeches (Hirudineans) in the teat canals or udders of cattle. J Am Vet Med Assoc 1959; 135:278.

34. Halton CM. Those amazing leeches. Minneapolis, MN: Dillon Press; 1989.

35. Tseng CC, Ho CY. Removal of a nasal leech: A safe and effective method. Otolaryngol Head Neck Surg 2005 132(5): 814-815.

36. Kuntz RE, Myers BJ. Helminths of vertebrates and leeches taken by the U.S. Naval Medical Mission to Yemen, Southwest Arabia. Can J Zool 1968; 46(5):1071-1075.

37. Ruckert F. Egel aus den Levante-Ländern (Clitellata: Hirudinea). Senckenb Biol 1985; 66:135-152.

38. Boye ES, Joshi DC. Occurrence of the leech Limnatis paluda as a respiratory parasite in man: case report from Saudi Arabia. J Trop Med Hyg 1994; 97(1):18-20.

39. Desilva PH, Anderson AA. A record of Dinobdella Ferox (Blanchard) (Hirudidae, Hirudinea) taken from the nasal cavity of man. Ann Trop Med Parasitol 1964; 58:1-2.

40. Campbell JR, Hart FL, Purnomo L. Nasal leech infestation of man. Trop Geogr Med 1987; 39(1):9495.

41. Makiya K, Tsukamoto M, Horio M, Kuroda Y. A case report of nasal infestation by the leech, Dinobdella ferox. J UOEH 1988; 10(2):203-209.

42. Cundall DB, Whitehead SM, Hechtel FO. Severe anaemia and death due to the pharyngeal leech Myxobdella africana. Trans R Soc Trop Med Hyg 1986; 80(6):940-944.

43. Estambale BB, Knight R, Chunge R. Haematemesis and severe anaemia due to a pharyngeal leech (Myxobdella africana) in a Kenyan child: a case report. Trans R Soc Trop Med Hyg 1992; 86(4):458.

44. Meyer MC. Another unusual case of erratic hirudiniasis. J Parasitol 1959; 45(4):59.

45. Smith DG. The rediscovery of Macrobdella sestertia Whitman (Hirudinea: Hirudinidae). J Parasitol 1977; 63(4):759-760.

46. Trauth SE, Neal RG. Geographic range expansion and feeding response by the leech Macrobdella diplotertia (Annelida: Hirudinea) to wood frog and spotted salamander egg masses. J Ark Acad Sci 2004; 58:139141.

47. Phillips AJ, Arauco-Brown R, Oceguera-Figueroa A, Gomez GP, Beltran M, Lai YT, et al. Tyrannobdella rex 
n. gen. $\mathrm{n}$. sp. and the evolutionary origins of mucosal leech infestations. PLoS ONE 2010; 5(4):e10057.

48. Saki N, Rahim F, Nikaghlagh S, Saki G. Meta analysis of the leech as a live foreign body: detection, precaution and treatment. Pak J Biol Sci 2009; 12(24):15561563.

49. El-Dib NA, El-Rahimy HH, El-Matarawy OM, Omar SH, Abdel-Salam NM. Leech infestation of man in Al-Taif, Saudi Arabia. J Egypt Soc Parasitol 1987; 17(2): 615618.

50. Pandey CK, Sharma R, Baronia A, Agarwal A, Singh N. An unusual cause of respiratory distress: Live leech in the larynx. Anesth Analg. 2000; 90(5):1227-1228.

51. Uygur K, Yasan H, Yavuz L, Dogru H. Removal of a laryngeal leech: A safe and effective method. Am J Otolaryngol 2003; 24(5):338-340.

52. Davis A, Appel T. Bloodletting instruments in the National Museum of History and Technology. Arlington, MA: The Printers' Devil; 1993.

53. Thear MJ. Leeches in medicine. Aust N Z J Surg 1998; 68:292-295.

54. Whitaker IS, Izadi D, Oliver DW, Monteath G, Butler $\mathrm{PE}$. Hirudo medicinalis and the plastic surgeon. $\mathrm{Br} \mathrm{J}$ Plast Surg 2004; 57(4):348-353.

55. Faust EC. Human Helminthology: A Manual for Physicians, Sanitarians and Medical Zoologists. $3^{\text {rd }}$ ed. Philadelphia, PA: Lea \& Febiger; 1949.

56. Deganc M, Zdravic F. Venous congestion of flaps treated by application of leeches. Br J Plast Surg 1960; 13:187-192.

57. Kraemer BA, Korber KE, Aquino TI, Engleman A. Use of leeches in plastic and reconstructive surgery. J Reconstr Microsurg 1988; 4(5):381-386.

58. Mumcuoglu KY, Pidhorz C, Cohen R, Ofek A, Lipton HA. The use of the medicinal leech, Hirudo medicinalis, in the reconstructive plastic surgery. Internet J Plast Surg 2007;4(2).

59. Michalsen A, Roth M, Dobos G. Medicinal leech therapy. New York, NY: Georg Thieme; 2007.

60. Green PA, Shafritz AB. Medicinal leech use in microsurgery. J Hand Surg Am 2010; 35(6):10191021.

61. Porshinsky BS, Saha S, Grossman MD, Beery Ii PR, Stawicki SP. Clinical uses of the medicinal leech: a practical review. J Postgrad Med 2011; 57(1):65-71.

62. Mumcuoglu KY. Recommendations for the use of leeches in reconstructive plastic surgery. Evidencebased complementary and alternative medicine. eCAM 2014; 2014:205929.

63. Sawyer RT, Damas D, Tomic MT. Anatomy and histochemistry of the salivary complex of the giant leech Haementeria ghilianii (Hirudinea, Rhynchobdellida). Arch Zool Exp Gen 1982; 122:411425.

64. Abdualkader AM, Ghawi AM, Alaama M, Awang M, Merzouk A. Leech therapeutic applications. Indian J Pharm Sci 2013; 75(2):127-137.

65. Rados C. Beyond bloodletting: FDA gives leeches a medical makeover. FDA Consum 2004; 38(5):9.
66. Shope RE. The leech as a potential virus reservoir. Exp Med 1957; 105:373-382.

67. Dickinson $\mathrm{MH}$, Leut CM. Feeding behavior of the medical leech, Hirudo medicinalis, L. J Comp Physiol [A] 1984; 154:449-455.

68. Adams SL. The medical leech. A page from the annelids of internal medicine. Ann Intern Med 1988; 109:399-405.

69. Nehili M, Ilk C, Mehlhorn H, Ruhnau K, Dick W, Njayou M. Experiments on the possible role of leeches as vectors of animal and human pathogens: a light and electron microscopy study. Parasitol Res 1994; 80(4):277-290.

70. Eldor A, Orevi M, Rigbi M. The role of the leech in medical therapeutics. Blood Rev 1996; 10(4):201209.

71. Utevsky SY, Trontelj P. A new species of the medicinal leech (Oligochaeta, Hirudinida, Hirudo) from TransCaucasia and an identification key for the genus Hirudo. Parasitol Res 2005; 98(1):61-66.

72. Utevsky S, Zagmajster M, Atemasov A, Zinenko O, Utevska O, Utevsky A, Trontelj, P. Distribution and status of medicinal leeches (genus Hirudo) in the Western Palaearctic: anthropogenic, ecological, or historical effects? Aquat Conserv Mar Freshw Ecosyst 2010; 20(2):198-210.

73. Trontelj P, Utevsky SY. Phylogeny and phylogeography of medicinal leeches (genus Hirudo): fast dispersal and shallow genetic structure. Mol Phylogenet Evol 2012; 63(2):475-485.

74. Sawyer RT. Why we need to save the medicinal leech. Oryx 1981; 16(02):165-168.

75. Elliott JM, Tullett PA. The status of the medicinal leech Hirudo medicinalis in Europe and especially in the British Isles. Biol Conserv 1984; 29:15-26.

76. Trontelj P, Utevsky SY. Celebrity with a neglected taxonomy: Molecular systematics of the medicinal leech (genus Hirudo). Mol Phylogenet Evol 2005; 34(3):616-624.

77. Tan E. A new species of the genus Poecilobdella from Guangdong and Hainan, China (Hirudinea, Hirudinidae). Acta Zootaxonomica Sinica 2006; 4:790-793.

78. El-Shimy N. Distribution of the medicinal leech, Hirudo medicinalis, in the Middle East. Zool Middle East 1986; 1(1):154-155.

79. Wittke-Michalsen E. The technique of leech therapy. In: Michalsen A, Roth M, Dobos G (Editors). Medicinal leech therapy. New York, NY: Thieme Medical Publishers; 2007.

80. MurdockJW. State-of-the-art study on leech repellents. Columbus, OH: Battelle Memorial Institute; 1963.

81. Kutschera U, Pfeiffer I, Ebermann E. The European land leech: biology and DNA-based taxonomy of a rare species that is threatened by climate warming. Naturwissenschaften 2007; 94(12):967-974.

82. Lai YT, Nakano T, Chen JH. Three species of land leeches from Taiwan, Haemadipsa rjukjuana comb. n., a new record for Haemadipsa picta Moore, and an 
updated description of Tritetrabdella taiwana (Oka). Zookeys 2011; 139:1-22.

83. Won S, Park BK, Kim BJ, Kim HW, Kang JG, Park TS, et al. Molecular identification of Haemadipsa rjukjuana (Hirudiniformes: Haemadipsidae) in Gageo Island, Korea. Korean J Parasitol 2014; 52(2):169-175.

84. Moore JP. Leeches (Hirudinea) from the Hawaiian Islands, and two new species from the Pacific region in the Bishop Museum collection. Occas Pap Bernice P Bishop Mus 1946; 18:171-191.

85. Ringuelet RA. Nuevos taxia de hirudineos neotropicos con la redefinicion de Semiscolecidae y la descripcion de Cylicobdellidae fam. Nov. y Mesobdellidae fam. Nov. Physis 1972; 31:193-201.

86. Richardson LR. A contribution to the general zoology of the land leeches (Hirudinoidea: Haemadipsoidea superfam. nov). Acta Zool Acad Sci Hung 1975; 21:119-152.

87. Richardson LR. On the zoological nature of landleeches in the Seychelle Islands, and a consequential revision of the status of landleeches in Madagascar (Hirudinea: Haemadipsoidea). Rev Zool Afr 1978; 92:837-866.

88. Nybelin 0. Nesophilaemon n. g. fur Philaemon skottsbergi L. Johansson aus den Juan Fernandez Inseln. Zool Anz 1943; 142:249-250.
89. Kvist S, Brugler MR, Goh TG, Giribet G, Siddall ME. Pyrosequencing the salivary transcriptome of Haemadipsa interrupta (Annelida: Clitellata: Haemadipsidae): anticoagulant diversity and insight into the evolution of anticoagulation capabilities in leeches. Invert Biol 2014; 133(1):74-98.

90. Smythies BE. Leeches of Borneo. Sarawak Mus J 1959; 13:279-294.

91. Moore JP. Arhynchobdellae. In: Harding WA, Moore JP (Editors). The Fauna of British India: Hirudinea. London, UK: Taylor and Francis; 1927. p. 97-295.

92. Moore JP. Leeches from Borneo with descriptions of new species. Proc Acad Nat Sci Philadelphia 1929; 81:267-295.

93. Harrison JL. Leeches. Med J Malaya 1953; 8(2):180185.

94. Nath DR, Das NG, Das SC. Bio-repellents for land leeches. Def Sci J 2002; 52(1):73-76.

95. Nath DR, Das NG, Das SC. Persistence of leech repellents on cloth. Indian J Med Res 1993; 97(A):128131.

96. Skinner WA, Johnson HL. The design of insect repellents. New York, NY: Academic Press; 1980. 